\title{
Wybrane aspekty bezpieczeństwa w sieci w prawodawstwie europejskim i w polskim systemie edukacji
}

DOI: $10.47050 / 65591777.90-114$

Rafał Lew-Starowicz

Działania profilaktyczne, w tym podejmowane w obszarze kształcenia na rzecz bezpieczeństwa uczniów w internecie, mają długą historię i zostały ugruntowane na płaszczyźnie prawa zarówno europejskiego, jak i krajowego. Aktywna postawa instytucji publicznych, wspierająca, koordynująca i nacechowana otwartością w stosunku do wszystkich interesariuszy procesu zapewnienia bezpieczeństwa uczniom podczas korzystania przez nich z technologii informacyjno-komunikacyjnych, jest jednym z ważniejszych wyznaczników skuteczności takich działań. Można uznać, że istniejące regulacje $w$ tym zakresie dają możliwość rozwoju polityki na rzecz bezpieczeństwa uczniów w środowisku szkolnym, co więcej - stanowią o wymogu jej realizacji. Przyjęty przez Komisję Europejską Plan działania w dziedzinie edukacji cyfrowej zakłada przeciwdziałanie zagrożeniom w sieci, a jednym z podstawowych zadań systemu oświaty w Polsce jest przygotowanie uczniów do bezpiecznej i odpowiedzialnej aktywności w internecie.

\section{Słowa kluczowe:}

\section{prawo oświatowe}

podstawa programowa

dyrektywy unijne

konwencje Rady Europy 


\section{Selected aspects of the e-Safety in the Pan-Huropean legislation and in the Polish education system}

DOI: 10.47050/65591777.90-114

Rafał Lew-Starowicz

Preventive measures in the e-safety area, including education, have a long history and have been addressed at the Pan European as well as at national level in Poland. Active attitude of public institutions that should support and coordinate, monitorize, and present openness in relation to all stakeholders of the process of ensuring the e-safety of students, is one of the most important determinants of the effectiveness of such policies. It can be assumed that the existing regulations in this area give an opportunity to develop policies for the e-safety of students in the school environment, what is more, they demanding its implementation. The Digital Education Action Plan adopted by the European Commission assumes the prevention of threats on the Internet and in relation to that, one of the basic goal of the education system in Poland is to prepare students for safe and responsible activity online.

\section{Keywords:}

\section{educational law}

\section{core curriculum}

EU directives

conventions of the Council of Europe 
Pierwsze działania skierowane przeciw nielegalnym treściom w sieci Rada Unii Europejskiej podjęła w lipcu 1996 r., przyjmując plan walki z rasizmem i ksenofobią. W 1997 r. Rada do spraw Telekomunikacji przyjęła rezolucję $w$ sprawie szkodliwych lub nielegalnych treści w internecie. W styczniu 1999 r. Parlament Europejski i Rada Europejska zaakceptowały Plan działania w zakresie promocji bezpiecznego korzystania z internetu poprzez walkę ze szkodliwymi lub nielegalnymi treściami w globalnych sieciach. Na mocy tego dokumentu uruchomiony został program Safer Internet Action Plan (SIAP), propagujący bezpieczne korzystanie $z$ internetu oraz z nowych technologii, $w$ tym z nowej generacji telefonów komórkowych, gier online, chatów i komunikatorów. W ramach programu realizowane są działania w następujących obszarach:

$\rightarrow$ poprawa bezpieczeństwa zasobów internetowych (przez samoregulację dostawców treści),

$\rightarrow$ rozwój systemów filtrowania i ratingu,

$\rightarrow$ popieranie działań uświadamiających,

$\rightarrow$ tworzenie sieci punktów kontaktowych do spraw zwalczania nielegalnych treści (hotline),

$\rightarrow$ działania wspierające (oceny projektów, badania i publikacje, konferencje, seminaria, końcową ocenę programu).

Pierwotnie Safer Internet Action Plan był przewidziany na lata 1999-2002. Kilka lat temu zakończyła się jego czwarta edycja (2009-2013). Jednym z głównych celów tej inicjatywy jest podnoszenie świadomości wszystkich użytkowników internetu w zakresie bezpiecznego i efektywnego korzystania z sieci. W ramach programu w całej Europie powstają narodowe punkty Awareness, których działalność koncentruje się na budowaniu świadomości zagrożeń, z jakimi w sieci mogą zetknąć się jej użytkownicy. Obecnie sieć Awareness obejmuje dziewiętnaście krajów. Ich współpracę na poziomie europejskim koordynuje organizacja INSAFE1.

Ocenę Safer Internet Action Plan zawarto w Komunikacie Komisji do Parlamentu Europejskiego, Rady, Europejskiego Komitetu Ekonomiczno-Społecznego i Komitetu Regionów: Ocena okresowa wieloletniego unijnego programu ochrony dzieci korzystających z internetu 
oraz innych technologii komunikacyjnych. Polski rząd przyjął w 2014 r. stanowisko wobec tego komunikatu, w którym dokonał oceny krajowego komponentu programu.

W dokumencie Komisji Europejskiej czytamy między innymi: „Program prowadzono w sposób wydajny [...]. Zgodnie z oceną program jest też skuteczny" ${ }^{2}$. W przedstawionej analizie podkreślono takie osiągnięcia programu jak powstanie numerów interwencyjnych, infolinii i ośrodków informacyjnych w większości państw członkowskich.

Ważnym wydarzeniem na szczeblu Komisji Europejskiej, mającym na celu wzmocnienie ochrony osób małoletnich w internecie, było przyjęcie Europejskiej strategii na rzecz lepszego internetu dla dzieci, umożliwiającej wspieranie:

$\rightarrow$ procesów ustalania i wymiany między państwami członkowskimi najlepszych praktyk w obszarach formalnego i nieformalnego nauczania bezpieczeństwa winternecie, tworzenia stosownych treści edukacyjnych oraz partnerstw publiczno-prywatnych, których celem jest dotarcie do dzieci, rodziców, nauczycieli i opiekunów,

$\rightarrow$ prac nad specjalnym modułem $w$ ramach systemu Europass, określającym kompetencje cyfrowe, a także nad poprawą wskaźników korzystania z technologii informacyjno-komunikacyjnych i ich wpływu na edukację,

$\rightarrow$ dokonywania analiz oraz testowania narzędzi kontroli rodzicielskiej i powiązanych usług wspierających, które mają na celu umocnienie praw rodziców i dzieci,

$\rightarrow$ badań i rozwoju, aby rozważyć możliwości interpretacji systemów ratingów wiekowych oraz klasyfikacji treści przez skuteczne narzędzia kontroli rodzicielskiej, które funkcjonowałyby w wielu językach,

$\rightarrow$ podejmowania kroków legislacyjnych, jeżeli metody samoregulacji branży nie przyniosą efektów³ ${ }^{3}$. -Społecznego i Komitetu Regionów: Ocena okresowa wieloletniego unijnego programu ochrony dzieci korzystających z Internetu oraz innych technologii komunikacyjnych, s. 5, bit.ly/2X9AgI0 [dostęp: 17.07.2018]. 
W strategii określono, jakie działania powinny spoczywać na państwach członkowskich, a jakie na sektorze usług internetowych w zakresie poprawy bezpieczeństwa dzieci w internecie. Komisja Europejska udziela wsparcia finansowego zarówno organizacjom zrzeszającym przedstawicieli rynku internetowego, takim jak Internet Content Rating Association (ICRA), jak i organizacjom rynku gier komputerowych i wideo, na którym działa na przykład Federacja Producentów Oprogramowania Interaktywnego (Interactive Software Federation of Europe, ISFE).

Stowarzyszenie ICRA powołało do życia tak zwany RSAC iRating System, który ma za zadanie filtrowanie zawartości internetu pod kątem występujących tam treści potencjalnie niebezpiecznych dla dzieci. Z kolei federacja ISFE stworzyła ogólnoeuropejski system klasyfikacji gier komputerowych i wideo PEGI (Pan-European Game Information), współfinansowany przez Komisję Europejską.

Wraz z rozwojem mediów cyfrowych dostrzeżono potrzebę stworzenia przepisów prawa, które odnoszą się do konkretnych sytuacji związanych z tym procesem. Dobrym przykładem takiego postępowania może być treść dyrektywy 2007/65/WE Parlamentu Europejskiego i Rady z dnia 11 grudnia 2007 r. zmieniającej dyrektywę Rady 89/552/EWG w sprawie koordynacji niektórych przepisów ustawowych, wykonawczych i administracyjnych państw członkowskich, dotyczących wykonywania telewizyjnej działalności transmisyjnej, w której w art. 44 stwierdzono: „Dostępność szkodliwych treści w audiowizualnych usługach medialnych nadal budzi niepokój prawodawców, przedsiębiorstw branżowych i rodziców. Pojawią się również nowe problemy, związane zwłaszcza z nowymi platformami i nowymi produktami. Dlatego niezbędne jest wprowadzenie przepisów służących ochronie fizycznego, umysłowego i moralnego rozwoju małoletnich oraz ochronie godności ludzkiej we wszystkich audiowizualnych usługach medialnych, w tym także w audiowizualnych przekazach handlowych" 4 .

Z kolei art. 45 tej dyrektywy podkreśla: „Należy zachować należytą równowagę między środkami podejmowanymi w celu ochrony fizycznego, umysłowego i moralnego rozwoju małoletnich i ochrony godności ludzkiej a podstawowym prawem do wolności słowa zawartym w Kar- 
cie Praw Podstawowych Unii Europejskiej. Celem tych działań, takich jak stosowanie osobistych numerów identyfikacyjnych (kodów PIN), systemów filtrowania lub oznaczania, powinno więc być zapewnienie odpowiedniego poziomu ochrony fizycznego, umysłowego i moralnego rozwoju małoletnich i ochrony godności ludzkiej, zwłaszcza w przypadku audiowizualnych usług medialnych na żądanie" 5 . Przepisy te zachęcają państwa członkowskie Unii Europejskiej do podejmowania konkretnych działań na rzecz zabezpieczenia dzieci przed szkodliwym wpływem mediów.

Dyrektywa Parlamentu Europejskiego i Rady 2011/92/UE z dnia 13 grudnia 2011 r. w sprawie zwalczania niegodziwego traktowania w celach seksualnych i wykorzystywania seksualnego dzieci oraz pornografii dziecięcej, zastępująca decyzję ramową Rady 2004/68/WSiSW6, zawiera zapis $\mathrm{w}$ art. 25:

"1. Państwa członkowskie podejmują środki niezbędne do zapewnienia szybkiego usunięcia stron internetowych zawierających lub rozpowszechniających pornografię dziecięcą utrzymywanych na ich terytorium oraz by dążyć do zapewnienia usunięcia takich stron utrzymywanych poza ich terytorium.

2. Państwa członkowskie mogą podejmować środki służące blokowaniu stron internetowych zawierających lub rozpowszechniających pornografię dziecięcą wśród użytkowników internetu na swym terytorium. Środki te muszą być wprowadzone w oparciu o przejrzystą procedurę i dostarczać odpowiednich gwarancji, w szczególności w celu zapewnienia ograniczenia blokowania do tego, co konieczne i współmierne, oraz informowania użytkowników o powodzie takiego blokowania. Gwarancje te mogą również obejmować możliwość uzyskania zadośćuczynienia sądowego"7.

Ponadto w orzeczeniu Europejskiego Trybunału Sprawiedliwości w sprawie 239/85 Giftmüll, Komisja przeciwko Królestwu Belgii, można przeczytać, że: „Każde państwo członkowskie musi realizować dyrektywę $w$ taki sposób, aby odpowiadało to wymogom bezpieczeństwa prawnego, a w związku z tym transpozycja dyrektywy powinna być 
zapewniona w przepisach krajowych mających bezwzględnie wiążący charakter"8. Stanowi to jasną wskazówkę, w jaki sposób państwa członkowskie mają implementować dyrektywy unijne do swojego prawodawstwa.

Od 2016 r. Obserwatorium do spraw Naruszeń Praw Własności Intelektualnej przy Urzędzie Unii Europejskiej do spraw Własności Intelektualnej (European Union Intellectual Propery Office, EUIPO) prowadzi projekt „IP in Education". W ramach projektu odbywają się cykliczne spotkania przedstawicieli państw członkowskich dotyczące praw własności intelektualnej w edukacji. Na spotkaniach jest poruszany temat obecności problematyki praw autorskich, patentów i znaków towarowych w podstawie programowej oraz zagadnienie propagowania tej tematyki w szkołach w wymiarze przedsiębiorczości, kreatywności i innowacyjności uczniów, z uwzględnieniem kwestii przygotowania materiałów edukacyjnych dla nauczycieli i uczniów.

W związku z działaniami prawnymi podejmowanymi na szczeblu Wspólnoty Europejskiej, odnoszącymi się do coraz popularniejszej formy rozrywki, jaką są gry komputerowe i wideo, warto wspomnieć o dwóch komunikatach Komisji do Parlamentu Europejskiego, Rady, Europejskiego Komitetu Ekonomiczno-Społecznego oraz Komitetu Regionów. Pierwszym jest Europejskie podejście do umiejętności korzystania z mediów w środowisku cyfrowym KOM(2007) 833, w którym umiejętność korzystania z mediów online określono między innymi jako: „wyposażenie użytkowników w odpowiednie narzędzia do krytycznej oceny treści online" ${ }^{9}$. Drugi dokument to Komunikat Komisji z 2008 r. w sprawie ochrony konsumentów, w szczególności osób małoletnich, w kwestii korzystania z gier wideo, wzywający państwa członkowskie i zainteresowane podmioty do "oceny możliwych negatywnych i pozytywnych skutków gier wideo, zwłaszcza ich wpływu na zdrowie"10.

Ważnym przepisem w zakresie inspirowania rynku do podejmowania porozumień na rzecz bezpieczeństwa dzieci i młodzieży (tak

8 Orzeczenie Europejskiego Trybunału Sprawiedliwości w sprawie 239/85 Giftmüll, Komisja przeciwko Królestwu Belgii, nr 7, Zb. Orz. 1986, s. 1661 (za: Zapewnienie skuteczności prawu Unii Europejskiej w prawie polskim. Wytyczne polityki legislacyjnej i techniki prawodawczej, Urząd Komitetu Integracji Europejskiej, Warszawa 2003). 
zwanej samoregulacji) jest dyrektywa z dnia 8 czerwca 2000 r. o handlu elektronicznym, w której w art. 16 mówi się o potrzebie wsparcia przez państwa członkowskie oraz Komisję Europejską między innymi „opracowywania przez stowarzyszenia i organizacje handlowe, zawodowe lub konsumenckie kodeksów postępowania na poziomie wspólnotowym, mających na celu właściwe wykonanie art. 5-15, [...] przekazywanie Państwom Członkowskim oraz Komisji przez stowarzyszenia lub organizacje handlowe, zawodowe lub konsumenckie oceny stosowania takich kodeksów postępowania oraz ich wpływu na praktykę i zwyczaje odnoszące się do handlu elektronicznego; opracowanie kodeksów postępowania dotyczących ochrony małoletnich oraz godności człowieka"11.

W następstwie szczytu społecznego w Göteborgu w listopadzie 2017 r. oraz konkluzji Rady Europejskiej z grudnia 2017 r. Komisja Europejska zainicjowała 17 stycznia 2018 r. nowe inicjatywy mające na celu: poprawę kluczowych kompetencji i umiejętności cyfrowych obywateli europejskich, propagowanie wspólnych wartości i podnoszenie świadomości uczniów na temat funkcjonowania Unii Europejskiej. Jedną z inicjatyw jest Plan działań na rzecz edukacji cyfrowej, zawierający listę przedsięwzięć, które Komisja Europejska we współpracy z państwami członkowskimi i zainteresowanymi podmiotami będzie wdrażać do końca 2020 r. Plan działań koncentruje się na rozwoju kompetencji cyfrowych (umiejętności, wiedzy i postaw) przydatnych w pracy i służących szerszemu uczestnictwu w życiu społecznym, a także na efektywnym wykorzystywaniu technologii w edukacji oraz użyciu danych i prognoz w celu poprawy systemów kształcenia.

Plan działań obejmuje trzy główne cele:

$\rightarrow$ lepsze wykorzystanie technologii cyfrowych w nauczaniu i uczeniu się,

$\rightarrow$ rozwijanie umiejętności cyfrowych potrzebnych do życia i pracy w czasach szybkich przemian cyfrowych,

$\rightarrow$ poprawę edukacji dzięki lepszej analizie danych i prognozowaniu.

Najważniejsze elementy zaproponowane w planie działań:

$\rightarrow$ Zwiększenie zainteresowania kobiet technologiami informacyjno-komunikacyjnymi oraz dziedzinami STEM (science, techno- 
logy, engineering \& math - nauka, technologia, inżynieria i matematyka) - Komisja Europejska zobowiązuje się współpracować z przedstawicielami przemysłu, organizacji pozarządowych i systemów kształcenia, aby zapewnić uczennicom możliwości rozwoju umiejętności cyfrowych oraz dostarczyć im wzorców i autorytetów w celu osiągnięcia uczestnictwa kobiet w studiach i zawodach $w$ tych dziedzinach na równi z mężczyznami. Komisja Europejska będzie zachęcać do tego, aby w ramach inicjatywy Europejskiego Tygodnia Kodowania odbywało się więcej lekcji kodowania dla dziewcząt. Będzie również współpracować z koalicją na rzecz umiejętności cyfrowych i zatrudnienia i innymi organizacjami w całej Europie w propagowaniu działań mających zachęcić dziewczęta i kobiety do rozwijania umiejętności cyfrowych.

$\rightarrow$ Wspieranie modernizacji szybkich łączy szerokopasmowych w szkołach - ponieważ istnieje wyraźna przepaść cyfrowa między państwami członkowskimi Unii Europejskiej, Komisja Europejska będzie działać na rzecz zmiany tego stanu rzeczy, między innymi przez utworzoną niedawno unijną sieć biur kompetencji w zakresie łączności szerokopasmowej. Komisja rozważy także wspieranie dostępu szkół do szybkich łączy internetowych, zwłaszcza przez system bonów, ze szczególnym uwzględnieniem obszarów w niekorzystnej sytuacji.

$\rightarrow$ Zapewnienie ram dla cyfrowo poświadczonych kwalifikacji i umiejętności - technologie cyfrowe umożliwiają zwiększenie wiarygodności i przejrzystości kwalifikacji oraz ochrony przed fałszowaniem dokumentów. Cyfrowe poświadczenia kwalifikacji są bardziej przenośne niż świadectwa papierowe - można je przechowywać na kilku serwerach lub w kilku instytucjach, ponadto mogą one zawierać obszerne metadane. Ułatwiają prezentowanie kwalifikacji w życiorysach zawodowych, mediach społecznościowych i na osobistych stronach internetowych. Ramy cyfrowo poświadczonych kwalifikacji zapewnią zwiększenie spójności danych i będą stanowić wsparcie na rzecz zapewniania jakości, ułatwią ponadto przenoszenie i porównywalność kwalifikacji oraz będą sprzyjać mobilności, rozwijaniu współpracy i wymianie pracowników.

$\rightarrow$ Propagowanie nauki kodowania - Komisja Europejska postawiła sobie za cel zaangażować w Europejski Tydzień Kodowania do 
2020 r. co najmniej połowę unijnych szkół. Europejski Tydzień Kodowania to dynamiczny oddolny ruch zmierzający do tego, aby rozpowszechnić umiejętność kodowania i inne umiejętności cyfrowe wśród Europejczyków, umożliwiając im zapoznanie się z podstawami programowania i zagadnieniami dotyczącymi między innymi sprzętu komputerowego, drukowania 3D, robotów. Zaznajomienie się nauczycieli i uczniów z podstawami programowania w ramach różnych przedmiotów pozwoli rozwinąć kompetencje w zakresie stosowania kodowania jako narzędzia nauczania umiejętności cyfrowych. W celu propagowania umiejętności kodowania Komisja Europejska będzie współpracować z ambasadorami Europejskiego Tygodnia Kodowania, państwami członkowskimi, siecią eTwinning, koalicją na rzecz umiejętności cyfrowych i zatrudnienia, liderami cyfryzacji oraz innymi zainteresowanymi instytucjami i organizacjami.

$\rightarrow$ Przeciwdziałanie zagrożeniom w internecie - coraz gęstsza sieć połączeń cyfrowych sprawia, że spada poziom cyberbezpieczeństwa, zwiększa się zagrożenie dla danych osobowych oraz ryzyko wystąpienia negatywnych zjawisk, w tym dotyczących nadużyć finansowych, rozpowszechniania fałszywych informacji, nękania w internecie i radykalizacji postaw. W związku z tym wszyscy muszą wiedzieć, jak zarządzać swoją obecnością w internecie i jak chronić swoje konta, informacje i urządzenia. Ważne jest zatem uczenie dzieci i młodzieży krytycznego myślenia i umiejętności korzystania z mediów. Niezależnie od wieku każdy musi być obywatelem świadomym cyfrowo - korzystać z możliwości, jakie oferują technologie informatyczne, zdając sobie jednocześnie sprawę ze związanych z nimi zagrożeń i rozwijając możliwości przeciwdziałania im. Unia Europejska będzie propagować działania edukacyjne i uświadamiające, mające na celu rozwijanie potencjału wszystkich obywateli Wspólnoty, aby stawali się aktywnymi, odpowiedzialnymi, krytycznymi i bezpiecznymi użytkownikami technologii.

$\rightarrow$ Uruchomienie unijnej kampanii dotyczącej higieny cybernetycznej oraz znajomości mediów, w tym mediów społecznościowych, a także skutecznych sposobów przeciwdziałania takim zagrożeniom jak cyberprzemoc, fałszywe informacje lub niepokoją- 
ce treści - kampania obejmie wszystkie zainteresowane strony i ma dotrzeć do dzieci, młodzieży, rodziców i wychowawców ${ }^{12}$.

\section{Rada Europy}

Postanowienia Konwencji Rady Europy o ochronie dzieci przed seksualnym wykorzystywaniem i niegodziwym traktowaniem w celach seksualnych, otwartej do podpisu w Lanzarote 25 października 2007 r., również potwierdzają potrzebę określenia ram współpracy na rzecz ochrony dzieci i młodzieży na szczeblu międzynarodowym w obliczu rozwoju mediów elektronicznych. W art. 23 konwencji zamieszczono zakaz nagabywania dzieci w celach seksualnych za pośrednictwem technologii informacyjnych i telekomunikacyjnych (grooming), co jest obecnie poważnym problem w związku z aktywnością pedofilów na wszelkiego rodzaju czatach i forach internetowych, z których korzystają dzieci.

Kwestie dotyczące przestępstw w internecie podjęto także 23 listopada 2001 r. podczas budapeszteńskiej Konwencji Rady Europy o cyberprzestępczości, w której określono nowe kategorie przestępstw dotyczących nielegalnego dostępu do danych informatycznych i systemów informatycznych, naruszenia ich integralności, fałszerstw i oszustw komputerowych, nielegalnego przechwytywaniem danych, a także produkowania, oferowania, udostępniania, rozpowszechniania, transmitowania oraz pozyskiwania pornografii dziecięcej za pomocą systemu informatycznego. W lipcu 2018 r. Komitet Ministrów Rady Europy przyjął specjalne wytyczne dla państw członkowskich w zakresie respektowania, ochrony i realizacji praw dzieci w środowisku cyfrowym ${ }^{13}$. Szczególnie ważne wydaje się wśród innych wymienionych w tym dokumencie zaleceń zapewnienie dzieciom dostępu do środowiska cyfrowego, co daje możliwość korzystania z pełni przysługujących im praw, rozwijania u dzieci umiejętności krytycznej analizy treści, ochrony przed zagrażającym im treściami oraz ochrony ich prywatności i danych osobowych. 


\section{Bezpieczeństwo uczniów $w$ internecie a polski system edukacji}

Najważniejsze w polskim systemie oświaty dokumenty mające wpływ na kwestie bezpieczeństwa uczniów w internecie to:

$\rightarrow$ ustawa z dnia 14 grudnia 2016 r. - Prawo oświatowe,

$\rightarrow$ ustawa $z$ dnia 7 września 1991 r. o systemie oświaty,

$\rightarrow$ rozporządzenie Ministra Edukacji Narodowej z dnia 14 lutego 2017 r. w sprawie podstawy programowej wychowania przedszkolnego oraz podstawy programowej kształcenia ogólnego dla szkoły podstawowej,

$\rightarrow$ rozporządzenie Ministra Edukacji Narodowej z dnia 30 stycznia 2018 r. w sprawie nowej podstawy programowej kształcenia ogólnego dla czteroletniego liceum ogólnokształcącego, pięcioletniego technikum oraz dwuletniej branżowej szkoły II stopnia.

Prawo oświatowe, które weszło w życie w 2017 r., jako jedno z podstawowych zadań systemu oświaty przewiduje upowszechnianie wśród dzieci i młodzieży wiedzy o bezpieczeństwie w internecie oraz kształtowanie właściwych postaw wobec zagrożeń, w tym związanych z korzystaniem z technologii informacyjno-komunikacyjnych i sytuacji nadzwyczajnych (art. 1 pkt 20). W pkt. 21 wymienia się kształtowanie u uczniów umiejętności sprawnego posługiwania się technologiami informacyjno-komunikacyjnymi. Do tej pory jako potencjalne zagrożenia traktowano klęski żywiołowe i inne stany nadzwyczajne, które mogły narazić na niebezpieczeństwo uczniów. W Prawie oświatowym zawarto jednak przepis art. 27, mówiący o tym, że "szkoły i placówki zapewniające uczniom dostęp do internetu są obowiązane podejmować działania zabezpieczające uczniów przed dostępem do treści, które mogą stanowić zagrożenie dla ich prawidłowego rozwoju, w szczególności zainstalować i aktualizować oprogramowanie zabezpieczające". Najczęściej interpretowano ten przepis jako konieczność zapewnienia odpowiednich zabezpieczeń wewnątrzszkolnych w zakresie korzystania $z$ internetu na lekcjach. Obecnie zwraca się uwagę na kwestie zdobycia wiedzy $w$ tym zakresie i przyjmowaniu właściwych postaw przez uczniów wobec zagrożeń związanych z korzystaniem z internetu, a zatem traktuje się ten problem znacznie szerzej niż wcześniej.

Bardzo ważnym elementem zapewnienia bezpieczeństwa uczniów jest odpowiednie przygotowanie nauczycieli. Jak wynika z badań, 
to do nich zwracają się uczniowie, szczególnie wtedy, gdy doświadczają problemów w sieci będących wynikiem działań innych osób (Kwiatkowska, Dąbrowski 2012).

Wyznaczenie standardów kształcenia nauczycieli to zadanie Ministerstwa Nauki i Szkolnictwa Wyższego. Zostały one określone w rozporządzeniu Ministra Nauki i Szkolnictwa Wyższego z dnia 17 stycznia 2012 r. w sprawie standardów kształcenia przygotowujących do wykonywania zawodu nauczyciela (Dz.U. 2012, poz. 131). Rozporządzenie to powstało w porozumieniu z ministrem edukacji narodowej, ponieważ doskonalenie nauczycieli to domena Ministerstwa Edukacji Narodowej. Zgodnie z ogólnymi efektami kształcenia określonymi w załączniku do tego dokumentu: „po zakończeniu kształcenia przygotowującego do wykonywania zawodu nauczyciela absolwent:

$\rightarrow$ posiada wiedzę psychologiczną i pedagogiczną pozwalającą na rozumienie procesów rozwoju, socjalizacji, wychowania i nauczania - uczenia się;

$\rightarrow$ posiada wiedzę z zakresu dydaktyki i szczegółowej metodyki działalności pedagogicznej, popartą doświadczeniem w jej praktycznym wykorzystywaniu;

$\rightarrow$ posiada umiejętności i kompetencje niezbędne do kompleksowej realizacji dydaktycznych, wychowawczych i opiekuńczych zadań szkoły, w tym do samodzielnego przygotowania i dostosowania programu nauczania do potrzeb i możliwości uczniów;

$\rightarrow$ wykazuje umiejętność uczenia się i doskonalenia własnego warsztatu pedagogicznego z wykorzystaniem nowoczesnych środków i metod pozyskiwania, organizowania i przetwarzania informacji i materiałów;

$\rightarrow$ umiejętnie komunikuje się przy użyciu różnych technik, zarówno z osobami będącymi podmiotami działalności pedagogicznej, jak i z innymi osobami współdziałającymi w procesie dydaktyczno-wychowawczym oraz specjalistami wspierającymi ten proces;

$\rightarrow$ charakteryzuje się wrażliwością etyczną, empatią, otwartością, refleksyjnością oraz postawami prospołecznymi i poczuciem odpowiedzialności; 
$\rightarrow$ jest praktycznie przygotowany do realizowania zadań zawodowych (dydaktycznych, wychowawczych i opiekuńczych) wynikających z roli nauczyciela" 14 .

Ustawa z dnia 26 stycznia 1982 r. - Karta Nauczyciela w art. 6 nakłada na nauczyciela obowiązek, aby: „kształcić i wychowywać młodzież w umiłowaniu Ojczyzny, w poszanowaniu Konstytucji Rzeczypospolitej Polskiej, w atmosferze wolności sumienia i szacunku dla każdego człowieka oraz dbać o kształtowanie u uczniów postaw moralnych i obywatelskich" ${ }^{15}$. Zapewnienie uczniom bezpieczeństwa w czasie pobytu w szkole należy do zadań dyrektora szkoły (art. 39 ust. 1 pkt 3 i 5 a ustawy o systemie oświaty; art. 68 ust. 1 pkt 5 Prawa oświatowego). Zasady bezpieczeństwa w szkołach określane są przez Ministerstwo Edukacji Narodowej w porozumieniu z Ministerstwem Rodziny, Pracy i Polityki Społecznej w rozporządzeniach (art. 95a ustawy o systemie oświaty; art. 125 Prawa oświatowego) ${ }^{16}$. Zasady dotyczące bezpieczeństwa i promocji zdrowia obowiązujące w konkretnej szkole są określone w statucie placówki. W tym zakresie obowiązek na szkołę nakłada rozporządzenie Ministra Edukacji Narodowej z dnia 21 maja 2001 r. w sprawie ramowych statutów publicznego przedszkola oraz publicznych szkół (Dz.U. 2001, nr 61, poz. 624). Od 1 września 2017 r. obowiązek ten wynika wprost z przepisu Prawa oświatowego (art. 98 ust. 1 pkt 4).

Kompetencje rad rodziców zostały określone w art. 54 ustawy o systemie oświaty (art. 83-84 Prawa oświatowego). Rada może występować z wnioskami i opiniami we wszystkich sprawach szkoły do dyrektora i innych organów szkoły lub organu sprawującego nadzór pedagogiczny i organu prowadzącego szkołę. Daje jej to uprawnienie także do zajmowania stanowiska w sytuacji, gdy dojdzie do niepokojących zdarzeń z udziałem uczniów, jak również do inicjowania działań profilaktycznych. Do kompetencji rady rodziców należy również uchwalenie w porozumieniu z radą pedagogiczną między innymi „programu w sprawie standardów kształcenia przygotowującego do wykonywania zawodu nauczyciela (Dz.U. 2012, poz. 131). wprowadzające ustawę - Prawo oświatowe (Dz.U. 2017, poz. 60). Przepisy rozporządzenia obowiązują do czasu wydania nowego rozporządzenia z art. 125 Prawa oświatowego. 
wychowawczo-profilaktycznego szkoły obejmującego wszystkie treści i działania o charakterze wychowawczym skierowane do uczniów, [...] programu profilaktyki" (Pilich 2009, s. 548). Odbywa się to na zasadach partnerskich między wspomnianymi organami, ponieważ ustawa jasno stwierdza, że działają one "w porozumieniu".

Inne uprawnienia ma rada szkoły, która uczestniczy w "rozwiązywaniu problemów szkoły", może "wnioskować do organu nadzorującego [...] o dokonanie oceny działalności szkoły", na przykład w zakresie osiąganych przez placówkę wyników w obszarach opieki i wychowania uczniów (Pilich 2009, s. 530-531). Rada rodziców uczestniczy również w procesie oceniania nauczycieli oraz udzielania im kolejnych stopni awansu zawodowego (art. 6a i 9c Karty Nauczyciela). Kurator oświaty, współdziałając $z$ właściwymi organami i organizacjami w sprawach przeciwdziałania patologii społecznej, ma również za zadanie wspierać szkoły w ich wychowawczej misji (art. 51 ust. 1 pkt 14 Prawa oświatowego).

Rozporządzenie Ministra Edukacji Narodowej z dnia 10 maja 2013 r. zmieniające rozporządzenie w sprawie nadzoru pedagogicznego ${ }^{17}$ określa wymagania dla szkół gimnazjalnych, które muszą być spełnione w związku z przeprowadzaną w nich ewaluacją zewnętrzną. Jednym z tych wymagań jest zorganizowanie w szkole procesów uczenia się sprzyjających respektowaniu norm społecznych. Polegają one na tworzeniu w placówce edukacyjnej środowiska zapewniającego uczniom bezpieczeństwo fizyczne i psychiczne, w którym „relacje między wszystkimi członkami społeczności szkolnej są oparte na wzajemnym szacunku i zaufaniu. Uczniowie współpracują ze sobą podczas realizacji przedsięwzięć będących wynikiem działań samorządu uczniowskiego. Zasady postępowania i współżycia w szkole lub placówce są uzgodnione i przestrzegane przez uczniów, pracowników szkoły i rodziców"18. Rozporządzenie mówi także o tym, że: „w szkole lub placówce, wspólnie $z$ uczniami i rodzicami, analizuje się podejmowane działania wychowawcze, w tym mające na celu eliminowanie zagrożeń oraz wzmacnianie 
właściwych zachowań. Ocenia się ich skuteczność oraz, w razie potrzeb, modyfikuje"19.

W obowiązującym stanie prawnym funkcjonują: rozporządzenie Ministerstwa Edukacji Narodowej z dnia 27 sierpnia 2015 r. w sprawie nadzoru pedagogicznego (Dz.U. 2015, poz. 1270) oraz rozporządzenie z dnia 6 sierpnia 2015 r. w sprawie wymagań wobec szkół i placówek (Dz.U. 2015, poz. 1214). Dotyczą one wszystkich etapów edukacji i rodzajów szkół. Zagrożenia online są również przedmiotem prac nad zmianą przepisów w sprawie bezpieczeństwa i higieny w publicznych oraz niepublicznych szkołach i placówkach. Nowe przepisy są dostosowywane do obecnej sytuacji i oczekiwań środowiska szkolnego. Dotychczasowe regulacje, z 2002 r. ${ }^{20}$, nie uwzględniają aktualnych potrzeb w zakresie bezpieczeństwa cyfrowego uczniów w szkołach.

\section{Podstawa programowa}

Zgodnie z zapisami rozporządzenia Ministra Edukacji Narodowej z 14 lutego 2017 r. w sprawie podstawy programowej wychowania przedszkolnego oraz podstawy programowej kształcenia ogólnego dla szkoły podstawowej, kształcenie ogólne w szkole podstawowej ma na celu między innymi:

$\rightarrow$ wprowadzanie uczniów w świat wartości, w tym wykształcenie u nich postaw ofiarności, współpracy, solidarności, altruizmu, patriotyzmu i szacunku dla tradycji, wskazywanie wzorców postępowania i budowanie relacji społecznych sprzyjających bezpiecznemu rozwojowi ucznia;

$\rightarrow$ rozwijanie umiejętności krytycznego i logicznego myślenia, rozumowania, argumentowania i wnioskowania.

Najważniejsze umiejętności rozwijane w ramach kształcenia ogólnego w szkole podstawowej to między innymi:

$\rightarrow$ poszukiwanie, porządkowanie, krytyczna analiza oraz wykorzystanie informacji z różnych źródeł;

19 Tamże.

20 Rozporządzenie Ministra Edukacji Narodowej i Sportu z dnia 31 grudnia 2002 r. w sprawie bezpieczeństwa i higieny w publicznych i niepublicznych szkołach i placówkach (Dz.U. 2003, nr 6, poz. 69, ze zm.) obowiązuje do czasu wydania nowego rozporządzenia na podstawie art. 125 Prawa oświatowego. 
$\rightarrow$ kreatywne rozwiązywanie problemów z różnych dziedzin ze świadomym wykorzystaniem metod i narzędzi wywodzących się z informatyki (z uwzględnieniem programowania).

Szkoła ma również przygotowywać do dokonywania świadomych i odpowiedzialnych wyborów w trakcie korzystania z zasobów internetu, do krytycznej analizy informacji, bezpiecznego poruszania się w przestrzeni cyfrowej, w tym nawiązywania i utrzymywania relacji z innymi użytkownikami sieci opartych na wzajemnym szacunku. Szkoła powinna dbać o wychowanie dzieci i młodzieży w duchu akceptacji i szacunku dla drugiego człowieka.

Działalność wychowawcza szkoły należy do podstawowych celów polityki oświatowej państwa. Wychowanie młodego pokolenia jest wspólnym zadaniem rodziny i szkoły. Placówki edukacyjne w swojej działalności muszą uwzględniać wolę rodziców, ale także państwa, do którego obowiązków należy stwarzanie właściwych warunków wychowania. Zadaniem szkoły jest ukierunkowanie procesu wychowawczego na wartości, które wyznaczają cele wychowania i kryteria jego oceny. Wychowanie ukierunkowane na wartości zakłada przede wszystkim podmiotowe traktowanie ucznia, który - dzięki wpojonym wartościom - może podejmować odpowiednie wybory lub decyzje.

W nowej podstawie programowej przedmiotu informatyka, która weszła do szkół z dniem 1 września 2017 r., na wszystkich etapach edukacji określono jednakowe cele ogólne, w tym dotyczące rozwijania kompetencji społecznych. Chodzi o takie elementy jak: komunikacja i współpraca w grupie (również w środowiskach wirtualnych), udział w projektach zespołowych oraz zarządzanie projektami, a także przestrzeganie prawa i zasad bezpieczeństwa, respektowanie prywatności informacji i ochrony danych, praw własności intelektualnej, etykiety w komunikacji i respektowanie norm współżycia społecznego, ocena zagrożeń związanych z technologią i ich uwzględnienie w zakresie zachowania bezpieczeństwa swojego i innych.

Osiągnięciu celu ogólnego nowej podstawy, dotyczącego rozwijania kompetencji społecznych, sprzyja masowe korzystanie uczniów ze społecznościowych środowisk wirtualnych. Zadaniem nauczyciela zajęć informatycznych jest wykorzystanie tego faktu do kształtowania właściwych postaw podczas komunikacji i współpracy w grupie, wska- 
zywanie możliwości bezpiecznego poruszania się w tych środowiskach oraz przygotowanie do pracy nad projektami zespołowymi.

Nowym elementem pojawiającym się w celach ogólnych jest rozszerzenie wcześniej funkcjonującego w podstawie programowej zapisu dotyczącego bezpieczeństwa o zagadnienia dotyczące przestrzegania prawa. Podkreślono, że respektowanie prywatności informacji, ochrona danych i praw własności intelektualnej, obok kwestii bezpiecznego poruszania się w cyberprzestrzeni, to bardzo ważne elementy właściwego funkcjonowania i rozwoju społecznego ucznia.

Interpretacja celów ogólnych dla poszczególnych etapów kształcenia jest zapisana w formie wymagań szczegółowych. Opis wymagań ma charakter spiralny (przyrostowy) - na każdym etapie edukacyjnym wymaga się od uczniów posiadania umiejętności zdobytych na wcześniejszych etapach i rozszerza się je o kolejne kwalifikacje.

W ramach edukacji informatycznej w klasach I-III wymagania szczegółowe dotyczące bezpiecznego poruszania się w cyberprzestrzeni wskazują, że uczeń:

"1) posługuje się udostępnioną mu technologią zgodnie z ustalonymi zasadami;

2) rozróżnia pożądane i niepożądane zachowania innych osób (również uczniów) korzystających z technologii, zwłaszcza w sieci internet;

3) przestrzega zasad dotyczących korzystania z efektów pracy innych osób i związanych z bezpieczeństwem w internecie" 21.

W ramach edukacji informatycznej w klasach IV-VIII określono następujące wymagania szczegółowe dotyczące bezpiecznego poruszania się w cyberprzestrzeni:

"Rozwijanie kompetencji społecznych. Uczeń:

1) uczestniczy w zespołowym rozwiązaniu problemu, posługując się technologią taką jak: poczta elektroniczna, forum, wirtualne środowisko kształcenia, dedykowany portal edukacyjny; programowej wychowania przedszkolnego oraz podstawy programowej kształcenia ogólnego dla szkoły podstawowej, w tym dla uczniów z niepełnosprawnością intelektualną w stopniu umiarkowanym lub znacznym, kształcenia ogólnego dla branżowej szkoły I stopnia, kształcenia ogólnego dla szkoły specjalnej przysposabiającej do pracy oraz kształcenia ogólnego dla szkoły policealnej (Dz.U. 2017, poz. 356). 
2) identyfikuje i docenia korzyści płynące ze współpracy nad wspólnym rozwiązywaniem problemów;

3) respektuje zasadę równości w dostępie do technologii i do informacji, w tym w dostępie do komputerów w społeczności szkolnej;

4) określa zawody i wymienia przykłady z życia codziennego, w których są wykorzystywane kompetencje informatyczne.

Przestrzeganie prawa i zasad bezpieczeństwa. Uczeń:

1) posługuje się technologią zgodnie z przyjętymi zasadami i prawem; przestrzega zasad bezpieczeństwa i higieny pracy;

2) uznaje i respektuje prawo do prywatności danych i informacji oraz prawo do własności intelektualnej;

3) wymienia zagrożenia związane z powszechnym dostępem do technologii oraz do informacji i opisuje metody wystrzegania się ich;

4) stosuje profilaktykę antywirusową i potrafi zabezpieczyć przed zagrożeniem komputer wraz z zawartymi w nim informacjami" 22 .

Realizacja podstawy programowej jest obligatoryjna dla wszystkich szkół i placówek systemu oświaty ${ }^{23}$.Za proces ten odpowiada dyrektor danej szkoły lub placówki, który również sprawuje nadzór pedagogiczny nad zatrudnionymi przez siebie nauczycielami. Podstawa programowa w szkołach i placówkach systemu oświaty realizowana jest w sposób ciągły podczas całego roku szkolnego.

Ustalając co roku priorytet polityki oświatowej państwa, minister edukacji narodowej wskazuje kierunek pożądanych przez państwo działań, którym powinny być podporządkowane prace szkoły. Analiza realizacji priorytetu „Bezpieczeństwo uczniów w sieci. Odpowiedzialne korzystanie z mediów społecznych" przez placówki doskonalenia zawodowego nauczycieli w roku szkolnym 2017/2018 dowodzi skuteczności tego narzędzia i potwierdza jego znaczne oddziaływanie na ofertę szkoleń nauczycieli. Szkolenia były realizowane we wszystkich województwach w Polsce i cieszyły się dużym zainteresowaniem. Ogółem w ramach priorytetu od 1 września 2017 do 22 czerwca 2018 r. zrealizowano ponad tysiąc szkoleń we wszystkich województwach. 
Od 1 września 2017 do 31 stycznia 2018 r. w województwie mazowieckim odbyło się 127 szkoleń dla nauczycieli z zakresu cyberbezpieczeństwa. Wzięło w nich udział 2530 nauczycieli ze szkół wszystkich typów. Szkolenia pod hasłem „Problemy wychowawcze związane z używaniem nowych mediów ze szczególnym uwzględnieniem cyberprzemocy" obejmowały wiele tematów związanych z obecnością uczniów w sieci, w tym: „Co naprawdę robią młodzi ludzie w internecie - szanse i zagrożenia”, „Uwarunkowania indywidualne i społeczne zaangażowania w cyberprzemoc", "Jak oswoić nowe media w szkole? - przykłady konkretnych rozwiązań".

W tym samym okresie w województwie podkarpackim przeprowadzono 31 szkoleń dla 538 nauczycieli wszystkich typów szkół. Przykładowe szkolenie o tematyce „Cyberzagrożenia, bezpieczeństwo dzieci i młodzieży w internecie" dotyczyło następujących zagadnień: narzędzia cyberprzestrzeni, klasyfikacja i skutki cyberzagrożeń oraz sposoby zapobiegania im, zabezpieczenia urządzeń informatycznych, dostępna pomoc, ochrona prawna czy uzależnienie od internetowej pornografii.

W województwie zachodniopomorskim do końca stycznia 2018 r. zrealizowano osiem szkoleń z zakresu cyberbezpieczeństwa. Te zorganizowane pod hasłem „Jak przeciwdziałać cyberprzemocy wśród uczniów" obejmowały następujące zagadnienia: zjawiska cyberprzestępczości i cyberprzemocy, sposoby identyfikacji cyberprzemocy oraz profilaktyka tego zjawiska, szybkie rozpoznanie i reakcja na zjawisko hejtowania oraz zawierania znajomości w sieci, kroki i działania zapobiegawcze, ochrona danych.

Dodatkowo we wszystkich województwach przeprowadzono szkolenia z ochrony danych osobowych w sieci oraz z zakresu prawa w internecie, z uwzględnieniem praw autorskich i korzystania z wolnego oprogramowania.

\section{Wybrane fragmenty treści podstawy programowej dotyczące zagadnienia bezpiecznego i odpowiedzialnego korzystania z komputera $\mathrm{i}$ internetu w szkole}

\section{Edukacja wczesnoszkolna, klasy I-III}

Do zadań szkoły w zakresie edukacji wczesnoszkolnej należy: zapewnienie dostępu do wartościowych, w wymiarze rozwoju ucznia, źródeł informacji i nowoczesnych technologii. 
Treści nauczania - wymagania szczegółowe:

\section{Edukacja społeczna}

Uczeń:

$\rightarrow$ przedstawia siebie i grupę, do której należy, zapisuje swój adres, adres szkoły, zawód i miejsce pracy rodziców;

$\rightarrow$ posługuje się danymi osobistymi wyłącznie w sytuacjach bezpiecznych dla siebie i reprezentowanych osób;

$\rightarrow$ jest powściągliwy w używaniu takich danych w sytuacjach nowych i wirtualnych.

\section{Edukacja przyrodnicza}

Osiągnięcia w zakresie funkcji życiowych człowieka, ochrony zdrowia, bezpieczeństwa i odpoczynku.

Uczeń:

$\rightarrow$ ma świadomość obecności nieprawdziwych informacji, na przykład w przestrzeni wirtualnej, publicznej; sprawdza informacje, zadając pytania nauczycielowi, rodzicom, policjantowi;

$\rightarrow$ stosuje zasady bezpieczeństwa podczas korzystania z urządzeń cyfrowych, rozumie i respektuje ograniczenia związane z czasem pracy z takimi urządzeniami oraz stosuje zasady netykiety;

$\rightarrow$ ma świadomość, że nieodpowiedzialne korzystanie z technologii ma wpływ na utratę zdrowia człowieka;

$\rightarrow$ ma świadomość pozytywnego znaczenia technologii w życiu człowieka.

\section{Edukacja informatyczna}

Osiągnięcia w zakresie przestrzegania prawa i zasad bezpieczeństwa. Uczeń:

$\rightarrow$ posługuje się udostępnioną mu technologią zgodnie $z$ ustalonymi zasadami;

$\rightarrow$ rozróżnia pożądane i niepożądane zachowania innych osób (również uczniów) korzystających z technologii, zwłaszcza w sieci internet;

$\rightarrow$ przestrzega zasad dotyczących korzystania z efektów pracy innych osób i związanych z bezpieczeństwem w internecie. 


\section{Klasy VII-VIII}

\section{Język polski}

III. Tworzenie wypowiedzi

Elementy retoryki

Uczeń:

$\rightarrow$ rozpoznaje i rozróżnia środki perswazji i manipulacji w tekstach reklamowych, określa ich funkcję;

$\rightarrow$ rozpoznaje manipulację językową i przeciwstawia jej zasady etyki wypowiedzi.

\section{Samokształcenie}

Uczeń:

$\rightarrow$ rzetelnie, z poszanowaniem praw autorskich, korzysta $z$ informacji.

\section{Warunki i sposób realizacji}

Zadaniem nauczyciela języka polskiego na II etapie edukacyjnym jest przede wszystkim:

$\rightarrow$ kształtowanie samodzielności w docieraniu do informacji, rozwijanie umiejętności ich selekcjonowania, krytycznej oceny oraz wykorzystania we własnym rozwoju;

$\rightarrow$ wychowanie do przyjmowania aktywnych postaw w życiu i brania odpowiedzialności za własne czyny.

\section{Wiedza o społeczeństwie}

Cele kształcenia - wymagania ogólne:

\section{Wiedza i rozumienie}

Uczeń:

$\rightarrow$ ma podstawową wiedzę na temat praw człowieka, środków masowego przekazu oraz wybranych spraw międzynarodowych.

III. Rozumienie siebie oraz rozpoznawanie i rozwiązywanie problemów

Uczeń:

$\rightarrow$ rozpoznaje przypadki łamania praw w swoim otoczeniu; 
$\rightarrow$ argumentuje zasadność postaw obywatelskich - między innymi odpowiedzialności, troski o dobro wspólne i tolerancji.

\section{Nieletni wobec prawa}

Uczeń:

$\rightarrow$ rozpoznaje zachowania związane z przemocą fizyczną i psychiczną, w tym: werbalną, wobec siebie i innych; wymienia osoby i instytucje, które należy powiadomić w takich sytuacjach;

$\rightarrow$ przedstawia korzyści i zagrożenia wynikające z korzystania z zasobów internetu;

$\rightarrow$ rozpoznaje przemoc w cyberprzestrzeni i wyjaśnia, jak należy na nią reagować.

\section{Informatyka}

\section{Klasy IV-VI}

\section{Przestrzeganie prawa i zasad bezpieczeństwa}

Uczeń:

posługuje się technologią zgodnie z przyjętymi zasadami i prawem;

$\rightarrow$ przestrzega zasad bezpieczeństwa i higieny pracy;

$\rightarrow$ uznaje i respektuje prawo do prywatności danych i informacji oraz prawo do własności intelektualnej;

$\rightarrow$ wymienia zagrożenia związane z powszechnym dostępem do technologii oraz do informacji i opisuje metody wystrzegania się ich;

$\rightarrow$ stosuje profilaktykę antywirusową i potrafi zabezpieczyć przed zagrożeniem komputer wraz z zawartymi w nim informacjami.

\section{Klasy VII-VIII}

\section{Przestrzeganie prawa i zasad bezpieczeństwa}

Uczeń:

$\rightarrow$ opisuje kwestie etyczne związane z wykorzystaniem komputerów i sieci komputerowych, takie jak: bezpieczeństwo, cyfrowa tożsamość, prywatność, własność intelektualna, równy dostęp do informacji i dzielenie się informacją;

$\rightarrow$ postępuje etycznie w pracy z informacjami;

$\rightarrow$ rozróżnia typy licencji na oprogramowanie oraz na zasoby w sieci. 


\section{Technika}

IV. Dostrzeganie wartości i zagrożeń techniki w aspekcie integralnego rozwoju człowieka i poszanowania jego godności

$\rightarrow$ Rozpoznawanie osiągnięć technicznych, które przysłużyły się rozwojowi postępu technicznego, a tym samym człowiekowi (lżejsza praca, komfort życia).

$\rightarrow$ Charakterystyka zagrożeń występujących we współczesnej cywilizacji spowodowanych postępem technicznych (wojny, terroryzm, zanieczyszczenie środowiska, zagrożenie zdrowia psychicznego i somatycznego).

$\rightarrow$ Przewidywanie zagrożeń ze strony różnych wytworów techniki i urządzeń technicznych.

\section{Wychowanie do życia w rodzinie}

Cele kształcenia - wymagania ogólne:

VII. Korzystanie ze środków przekazu, w tym z internetu, w sposób selektywny, umożliwiający obronę przed ich destrukcyjnym oddziaływaniem

Treści nauczania - wymagania szczegółowe:

II. Dojrzewanie

Uczeń:

$\rightarrow$ zna zagrożenia okresu dojrzewania, takie jak: uzależnienia chemiczne i behawioralne, presja seksualna, pornografia, cyberseks, prostytucja nieletnich;

$\rightarrow$ potrafi wymienić sposoby profilaktyki i przeciwdziałania.

\section{Człowiek a świat ludzkich wytworów}

Uczeń:

$\rightarrow$ podejmuje namysł nad problemem własności intelektualnej; wyjaśnia czym jest plagiat oraz formułuje ocenę moralną dotyczącą plagiatu;

$\rightarrow$ podaje przykłady właściwego i niewłaściwego wykorzystywania nowoczesnych technologii informacyjnych. 
Podstawa programowa kształcenia ogólnego dla czteroletniego liceum ogólnokształcącego i pięcioletniego technikum

Do najważniejszych umiejętności zdobywanych przez ucznia w trakcie kształcenia ogólnego w liceum ogólnokształcącym i technikum należą:

$\rightarrow$ umiejętność sprawnego posługiwania się nowoczesnymi technologiami informacyjno-komunikacyjnymi, w tym dbałość o poszanowanie praw autorskich i bezpieczne poruszanie się w cyberprzestrzeni.

\section{Informatyka}

V. Przestrzeganie prawa i zasad bezpieczeństwa

Uczeń:

$\rightarrow$ objaśnia rolę technik uwierzytelniania, kryptografii i podpisu elektronicznego w ochronie i dostępie do informacji. Stosuje dobre praktyki w zakresie ochrony: informacji wrażliwych (na przykład hasła, PIN), danych i bezpieczeństwa systemu operacyjnego;

$\rightarrow$ opisuje szkody, jakie mogą spowodować działania pirackie w sieci, w odniesieniu do indywidualnych osób, wybranych instytucji i całego społeczeństwa. 
